\title{
SZEXUÁLIS TELJESÍTÉS, FÉRFIPROBLÉMÁK ÉS ORVOSI MEGOLDÁSUK
}

\section{SEXUAL PERFORMANCE AND TREATMENT OF MALE SEXUAL DYSFUNCTIONS}

\author{
Kopa Zsolt ${ }^{1}$, Papp György ${ }^{2}$ \\ ${ }^{1} \mathrm{PhD}$, egyetemi docens, Semmelweis Egyetem Urológiai Klinika Andrológiai Centrum, Budapest \\ 2osztályvezető főorvos, Magyar Honvédség Egészségügyi Központ Urológiai és Andrológiai Osztály \\ kopaandro@gmail.com
}

\begin{abstract}
ÖSSZEFOGLALÁS
A férfiegészség egyik meghatározó részét jelenti a szexuális egészség. Egyrészt fontos szerepet tölt be a felnőtt férfiak életminőségében, másrészt kihat a párkapcsolat összhangjára is. Közleményünkben a férfiakat érintő két leggyakoribb szexuális zavarról írunk. A korai magömlés - amely az egyéni frusztráció mellett kezelés nélkül akár párkapcsolati válsághoz vezethet - és a merevedési zavar (erektilis diszfunkció) kerül jelenleg megtárgyalásra. Összefogó képet kívánunk adni a két kórkép korszerű megközelítéséről: a kórokok pontos megismerésének fontosságáról és módjáról, a kórismézés folyamatáról, és részletezzük a jelenlegi szakmai irányvonalak kezelési útmutatóit. Ezzel is elő kívánjuk segíteni, hogy a problémáról egyre több férfi tájékozódjon, az érintettek pedig egyre kevesebb fenntartással forduljanak szakemberhez.
\end{abstract}

\begin{abstract}
Sexual health is a major part of men's health. On the one hand, it plays an important role in the quality of life of adult men, on the other hand, it also affects the harmony of the relationship. In our present review, we describe two of the most common sexual disorders affecting men. Premature ejaculation, which can cause individual frustration and can lead to a relationship crisis, and erectile dysfunction are currently being discussed. A concise picture is given about the modern management to the two diseases including the importance and way of the correct pathomechanism, the diagnostic procedure, and treatment recommendations by the current international guidelines. The other aim of this review is to make more men aware of the problem and helping the decision to seek medical help.
\end{abstract}

Kulcsszavak: férfiegészség, szexuális zavarok, korai magömlés, merevedési zavar, kórisme, kezelés

Keywords: men's health, sexual problems, premature ejaculation, erectile dysfunction, diagnostics, treatment 


\section{BEVEZETÉS}

A férfiak leggyakoribb szexuális zavara a korai magömlés, amely a szexuálisan aktív férfiak $25 \%$-át érinti. A második leggyakoribb a merevedés zavara, amely viszont kiemelkedő jelentőségü az általános orvostudomány szempontjából is, ugyanis hátterében olyan betegségek lapulhatnak meg, amelyek akár az életet is veszélyeztetik.

\section{KORAI MAGÖMLÉS}

A szexuális élet zavarai egyrészt az érintett férfi számára jelenthetnek frusztrációt, de teljesen érthető módon párkapcsolati zavarokhoz is vezethetnek. Már a Bibliában is fellelhetö a magömlés fogalma, megengedett csak az utódnemzés céljából, a hüvelyben történő ejakuláció volt. Onán földre vesztegetett magja adta a napjainkban is használt onánia kifejezés alapját. Indiában a Káma-Szútra is foglalkozott a kérdéssel, a 16. században Tunéziában megjelent Illatos kert a korai magömlés specifikus megközelítését tartalmazza, bár kezelési tanácsokat nem ad. Annak ellenére, hogy a zavar ismerete ilyen régi múltra tekint vissza, pontos definíció megalkotására csak a 20. század dereka után törekedtek elődeink.

A korai magömlésben érintett férfiak könnyen észreveszik a zavart, sőt partnereik is észlelik a kóros eltérést. Orvosi felderítése azonban nem egyszerủ feladat. Csak az 1970-es évekre datálódnak ennek a szexuális zavarnak pontos meghatározására irányuló törekvések. William H. Masters és Virginia E. Johnson próbálták először megfogalmazni a korai magömlés lényegét. Az 1970-ben kiadott könyvükben leírtak szerint ,az ejaculatio praecox (EP) az az állapot, amikor a férfi nem képes magömlését vaginális közösülés során megfelelö időtartamban kontrollálni, és így partnere nem jut el az orgazmusig, legalább az esetek felében". Ez a definíció tehát a női orgazmusra fókuszált, de nem vette figyelembe a női szexuális zavarok esetleges jelenlétét. A megfogalmazás további finomítására a 21. század elejéig kellett várni. A máig legmegfelelőbb definíció 2004-ben, a Nemzetközi Szexuális Medicina Társaság (International Society for Sexual Medicine, ISSM) által fogalmazódott meg: ,az EP olyan szexuális funkciózavar, amelyre jellemző az ejakuláció megtörténte már a hüvelybe hatolás előtt vagy utána egy percen belül, minden vagy majdnem minden alkalommal, képtelenséget jelent az ejakuláció késleltetésére. Mindez negatív perszonális következményekkel jelenik meg: aggodalom, kellemetlenség, frusztráció, zavarva a szexuális kapcsolatot." Tehát objektív mérést végzünk: a hüvelyi behatolástól az ejakulációig eltelt időt mérjük, így kapjuk az ún. IELT- (intravaginal ejaculatory latency time) mértéket. Az időközben szerzett szakmai tapasztalatok alapján ma már a mérést nem kell elvégezni, az érintettek retrospektív módon, pontosan meg tudják határozni az 
IELT mértékét. Azt is tudjuk azonban, hogy az IELT sokkal inkább megfelelő a terápia hatékonyságának mérésére, mintsem diagnosztikai célra. A szakmai ajánlások szerint a csökkent IELT mellett fel kell térképezni a pár szexuális szokásait, valamint, hogy a zavar mióta és milyen gyakran jelentkezik, milyen mértékü szexuális stimulus okoz ejakulációt, és jelent-e ez a zavar egyéni vagy párkapcsolati problémát.

A korai magömlés egyik alaptípusa a szexuális aktivitás kezdete óta meglévő probléma (közel minden esetben korán történik meg az ejakuláció, a panasz partnertől független, és föleg pszichés eredetü), a másik pedig a szerzett változat (az élet egy pontján jelentkezik, korábbi normális szexuális funkciót követően, általában szervi okokra vezethető vissza, az ok megszüntetésével eredményesen kezelhető). Epidemiológiai adatok alapján előfordulása kb. 25\%, tehát minden negyedik férfi érintett ebben a zavarban. Kevesebben keresnek rá orvosi megoldást, mint merevedési zavarra, az érintettek 10\%-a beszél orvossal problémájáról, a kezelést kapók aránya pedig természetesen jóval ez alatt van.

Napjainkban már létezik gyógyszeres kezelés, az aktus előtt alkalmazott dapoxetin hatóanyag jelentős mértékben tudja növelni az IELT mértékét; lokális kezeléssel kombinálva még jobb eredményesség érhető el. Korai magömlés esetén a szexuálpszichológiai terápia a sikeres kezelés egyik alappillére.

\section{MEREVEDÉSI ZAVAR}

Maga a merevedés tulajdonképpen egy hemodinamikai történés, amely idegrendszeri, érrendszeri és hormonális szabályozás alatt áll. A folyamat fiziológiájának feltérképezése adott, és lehetőséget ad a diagnosztika és a terápia fejlődésének.

A barlangos testek anatómiai felépítése speciális: az artériák oszlásával öblök jönnek létre. Szexuális ingerek hatására ezek az öblök megtelnek vérrel, a barlangos test tágul, az elvezető vénás rendszer a kötőszövetes tokhoz nyomódik, komprimálódik, tehát gátolttá válik a vér eláramlása, és így létrejön az erekció. A folyamat biokémiai alapja a barlangos testek artériáinak tágulása, ennek feltétele pedig az érfal simaizomzatának elernyedése. Jelenlegi tudásunk szerint a szexuális ingerek hatására az ér endotél sejtjeiből felszabaduló nitrogén-monoxid a barlangos test artériáinak simaizomsejtjeibe jutva a ciklikus GMP- (guanozin-monofoszfát) rendszeren keresztül hat. A cGMP indítja be azt a bonyolult mechanizmust, amelynek végén az intracelluláris kalcium szintjének változása a simaizom elernyedését eredményezi. Az így létrejött értágulat megnövekedett vérbeáramláshoz, így erekcióhoz vezet. A megfelelő merevedés létrejöttéhez szükséges az intakt hormonrendszer. Bár a tesztoszteron szerepe közvetlenül az erekció kialakulásában nem teljesen tisztázott, hiányában merevedési zavar alakul ki. 


\section{A MEREVEDÉSI ZAVAR MEGHATÁROZÁSA}

A merevedési zavar vagy a szakirodalomban használt erektilis diszfunkció (ED) a megfelelö szexuális teljesítményhez szükséges merevedés elérésének vagy fenntartásának képtelensége, amely tartósan (legalább három hónapja) fennáll, vagy visszatéróen jelentkezik. Az ED valamilyen (enyhe, közepes vagy teljes) fokú előfordulása a negyven és hetven év közötti férfiak kb. felét érinti, előfordulása egyértelmüen életkorfüggő. Közel 80\%-ban szervi ok áll a háttérben, ez az ok pedig leggyakrabban éreredetü. Az ED lehet azonban neurogén kórokú, de hátterében állhatnak anatómiai eltérések, endokrin faktorok vagy gyógyszerek mellékhatásai is.

\section{KOCKÁZATI TÉNYEZŐK}

Az ED általános orvosszakmai jelentőségét a rizikófaktorok adják, a merevedési zavar sok esetben az egyetlen tünet, ami a háttérben húzódó, akár életet veszélyeztető betegségekre felhívja a figyelmet!

A merevedési zavarok kockázati tényezőiként legnagyobb arányban a szív- és érrendszeri betegségek fordulnak elö, de hasonlóan nagy jelentőségü a cukorbetegség is (érrendszeri és beidegzést egyaránt kárósító hatása miatt). Fontos faktor a zsíranyagcsere zavara, valamint a férfihormon (tesztoszteron) hiánya és a prosztatabetegségek, illetve azok kezelése. Radikális kismedencei sebészeti beavatkozások következtében is gyakran alakul ki merevedési zavar. Anatómiai rendellenességek, sérülések is okozhatnak szexuális diszfunkciót. Több olyan gyógyszer is ismert - akár szív- és érrendszeri betegségek, akár daganatos kórképek kezelésére vonatkozóan -, amelyek egyértelmüen károsítják a szexuális funkciót. Főleg fiatalabb életkorban fontos tényező a pszichiátriai betegségek előfordulása. Az életmódfaktorok között elsősorban a fizikai aktivitás hiánya emelendő ki, de különösen fontos szerepet játszik a dohányzás, a rendszeres alkohol- és drogfogyasztás mint jelentős súlyosbító tényező.

A Semmelweis Egyetem Urológiai Klinika Andrológiai Centrumában végzett kutatás adatai alapján a legfontosabb kockázati tényezők közül az érrendszeri faktorok előfordulása meghaladta a vizsgált férfiak 60\%-át, így egyértelmüen ez volt a leggyakoribb szervi ok. A páciensek közel felénél, összesen 48,2\%-ánál fordult elő valamilyen kardiovaszkuláris betegség (a hipertóniát is beleszámítva). Önmagában a magas vérnyomás 28,6\%-ban fordult elő, egyéb szív- és érrendszeri betegség nélkül. A zsíranyagcsere zavara 41\%-ban derült ki, ezen férfiak csaknem felénél (a teljes vizsgált populáció 20\%-a) találtunk eddig nem ismert hiperlipidémiát és/vagy hiperkoleszterinémiát, manifesztálódott magasvérnyomás-betegség vagy egyéb szív- és érrendszeri betegség nélkül. A betegcsoportban 12,5\%-ban 
találtunk igazolt cukorbetegséget, az ED kórismézése során végzett laborvizsgálatok viszont több férfinál is emelkedett vércukorértékre hívták fel a figyelmet, a férfiak közel 4\%-ában derült fény eddig nem ismert cukorbetegség előfordulására, így összesen 16,1\%-os volt a szénhidrátháztartás zavara. Érdekességként említendő, hogy a pszichiátriai kezelésen valaha átesett betegek (a vizsgáltak 12,5\%-a) többsége $(71,4 \%)$ ötven év alatti volt. Ez is mutatja a különbözö pszichés kórképek főleg a fiatalabb korosztály ED-jében betöltött kóroki szerepét. A rizikófaktorok következő nagy csoportját az életmódi tényezők, ezen belül is az élvezeti szerek alkotják. Kiemelkedő volt felmérésünkben a dohányzás 37,5\%-os előfordulása. Összehasonlításul a Nemzeti Egészségfejlesztési Intézet (NEFI) adatai szerint az Európai Unióban a lakosság 29\%-a dohányzik, míg hazai adatok szerint ez az arány Magyarországon 35,5\%, tehát a vizsgált populációban talált érték valamelyest meghaladja a magyarországi átlagot. Rendszeres alkoholfogyasztásról fele ennyi páciens, pontosan betegeink 17,9\%-a számolt be, míg a WHO legfrissebb adatai szerint a magyarországi alkoholfogyasztás a világátlag kétszerese: a felnőtt lakosság 25,7\%-a fogyaszt rendszeresen alkoholt. A hormonvizsgálatok szerint a tesztoszteronszintek átlaga $15,0 \mathrm{nmol} / \mathrm{l}$-nek bizonyult, ami a jelenlegi szakmai irányelvek szerint a normál tartományba tartozik, a páciensek 8,9\%-ánál mutattunk ki kórosan alacsony férfihormonszintet.

\section{DIAGNOSZTIKA}

A kórisme felállításának első lépcsője, hogy az érintett férfi, észlelve a zavart, megfogalmazza panaszait, szembenéz magával, és jelentkezik kivizsgálásra. A diagnosztika első lépése pedig a páciens és a partner korrekt orvosi és pszichoszociális anamnézisének felvétele. Az orvos egyik első feladata a panaszok objektivizálása is, amit kérdőívek segítségével tehetünk meg. Számos ilyen, hivatalosan magyar nyelvre lefordított kérdéssor létezik. A magyar nyelvü, validált kérdőívek közé tartozik a - nemzetközileg leginkább elfogadott és tudományos felmérésekben is leggyakrabban alkalmazott - tizenöt kérdésből álló IIEF (International Index for Erectile Function). A kérdöív rövidített változata (IIEF-5) is használatos a mindennapi klinikai kutatásokban, és ennek is létezik magyar változata, az ötkérdéses MMM (Merevedés Minőségi Mutatója) kérdőív. Míg az IIEF a szexuális élet különböző területeire kérdez rá (merevedési funkció, orgazmus, szexuális vágy, szexuális elégedettség, általános elégedettség), addig az MMM célzottan az erekciós képességet méri fel. Az MMM esetében a kérdésekre 0-tól 5-ig terjedő egész szám megadásával válaszolva számszerüsíthetővé válik a panaszok súlyossága. Az összpontszám segít eldönteni, hogy az adott esetben valóban van-e merevedési zavar, illetve hogy az milyen fokú. Az öt kérdésre öszszesen 25 pont adható egészséges szexuális teljesítmény esetén. Ha ez a szám 
22-25 pont közötti, valószínütlen az ED, 17-21 pont között enyhe, 12-16 pont között enyhe-középsúlyos, 8-11 pont közt középsúlyos, 5-7 pont közt pedig súlyos fokú merevedési zavarról beszélünk.

\section{A merevedési zavar (erektilis diszfunkció, ED) diagnosztikája}

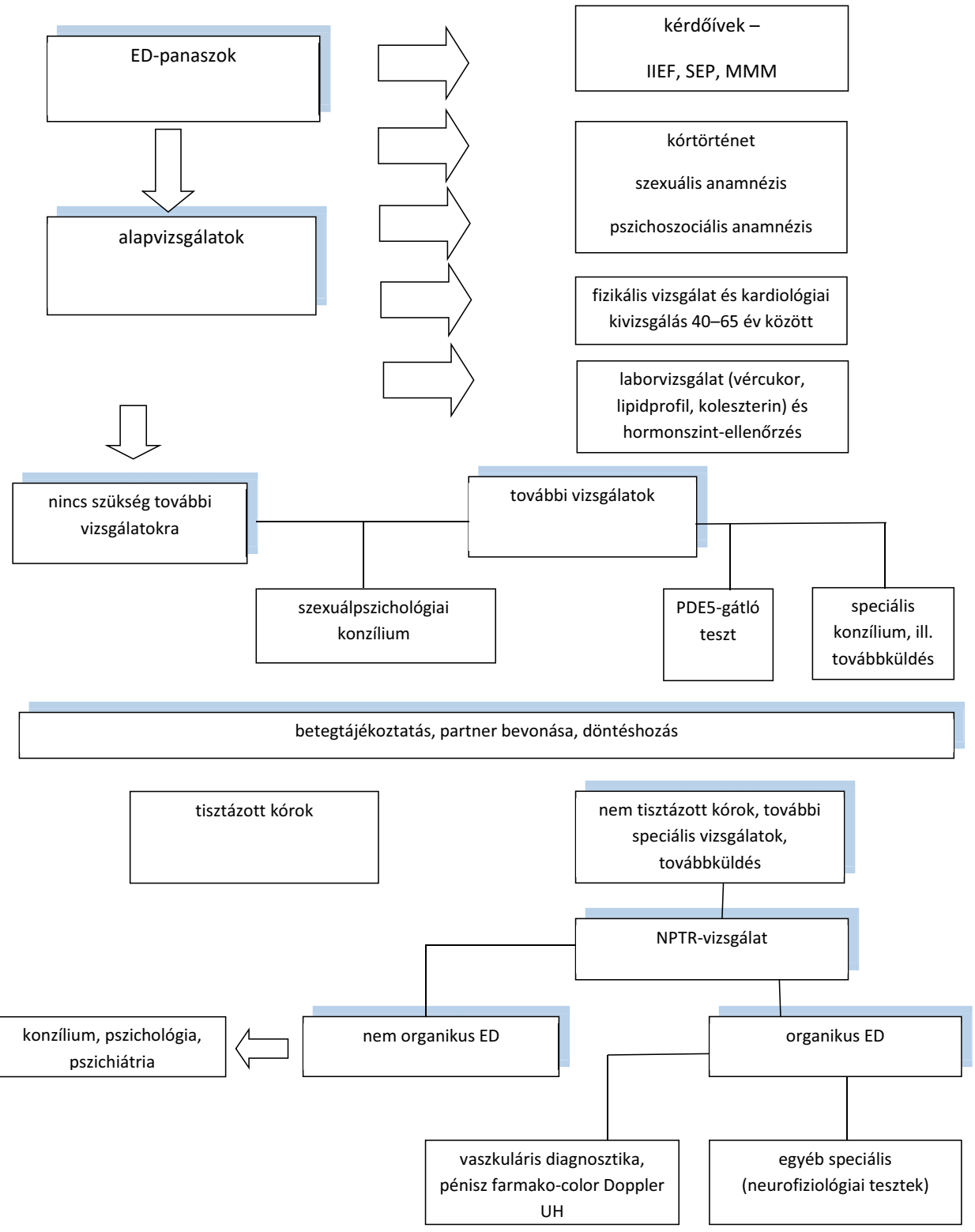

1. ábra. A merevedési zavarok kórismézésének folyamatábrája 
A kórismézés során elkülönítjük az egyéb szexuális zavarokat, meghatározzuk az ED hátterében a szervi és lelki tényezők arányát. Fel kell mérni a szexuális stimulusra létrejövő és a reggeli erekciók minőségét, a rigiditás fokát és a merevedés időtartamát. Ellenőrizzük a leggyakoribb oki tényezőket, a rizikófaktorokat, fel kell térképezni azokat, amelyek megváltoztathatók! A kórtörténet része az általános, a szexuális és a pszichoszociális anamnézis. A fizikális vizsgálat során a külső nemi szervek, a hímvessző, a prosztata, valamint a másodlagos nemi jellegek vizsgálata, a hipogonadizmus jegyeinek ellenőrzése a legfontosabb.

A merevedési zavar szoros összefüggést mutat a szív- és érrendszeri betegségek előfordulásával, és mint tünet sokszor ezek előhírnöke. ED esetén a negyven és ötven év közötti korosztályban közel 50-szer, az ötven és hatvan év közöttieknél több mint 20-szor gyakrabban fordul elö kardiovaszkuláris esemény, öszszehasonlítva potens kortársaikkal, és a különbség - igaz kisebb arányban - a hatvan-hetven év közöttieknél is megfigyelhetö. Így a mai szakmai irányvonalak szerint ED esetén az alap fizikális vizsgálatok közé soroljuk a kardiológiai státusz felmérését (rizikócsoportnak megfelelő protokoll szerint)! Neurogén károsodás lehetősége esetén ideggyógyászati vizsgálat szükséges. A diagnosztika része a szexuálpszichológiai exploráció.

Az általános laboratóriumi vizsgálatok közül merevedési zavar esetén a vércukor-, a koleszterin- és triglicerid-vizsgálatok, a vérkép, vese- és májfunkció fontossága emelhető ki. A hormonvizsgálatok során az összes és a szabad tesztoszteron (reggeli vérmintából), a prolaktin, az FSH, az LH szintjét ellenőrizzük, a pajzsmirigyfunkció vizsgálata (TSH) is javasolt. Célszerü a negyvenöt év feletti korosztályban a prosztatarák szüréseként a prosztataspecifikus antigén (PSA) meghatározása. A vizsgálatok eredményeit értékelve döntünk arról, hogy szükség van-e további speciális tesztekre (éjszakai tumeszcencia és rigiditás vizsgálata, intrakavernózus injekció beadása mellett végzett speciális, színes Doppler-ultrahangos vizsgálat stb.).

\section{KEZELÉS}

Az ED kezelésének alapja a zavar hátterében lévő ok felderítése és annak kezelése, nemcsak az ED mint tünet terápiája. A háttérben álló betegségek korrekt terápiája, illetve karbantartása, az életmódbeli tényezők optimalizálása - a káros szenvedélyek elhagyása, rendszeres testmozgás, testsúlykontroll - alappillére a sikeres terápiának. Emellett persze a megfelelő erekció elérése és fenntartása további kezelést igényel, erre kitünő terápiás lehetőségeink vannak.

A merevedés intracelluláris biokémiájának megismerése forradalmi változásokhoz vezette az ED kezelését. A barlangos test artériáinak simaizom-sejtjei nitrogén-monoxid (NO), valamint ciklikus guanozin-monofoszfát (cGMP) mediálta 
reakciók eredményeképpen ernyednek el, így tud megnövekedni a vér beáramlása. A ciklikus GMP-t az 5-ös típusú foszfodiészteráz (PDE5) enzim folyamatosan bontja. Ennek az enzimnek a gátlása tehát a relaxáció irányában fejti ki hatását. A merevedési zavarok kezelésében első vonalban választandó ez a gyógyszeres kezelés. A PDE5-gátló terápia átlagos hatékonysága 70\% körüli, a legnehezebben kezelhető (cukorbeteg és prosztatarákos) populációban az effektivitás alacsonyabb, míg az átlagnépességben magasabb. A mellékhatások enyhék, átmenetiek és ritkák. A kezelésre nem reagálók általában súlyos neurológiai károsodást szenvedtek, radikális prosztatamütéten estek át, vagy súlyos cukorbetegek, illetve súlyos érrendszeri betegségben szenvedők. PDE5-gátló adása ellenjavallt a nitrát(nitrit-) tartalmú gyógyszerkezelésben részesülők vagy instabil kardiovaszkuláris státuszú betegek számára. Az első vonalbeli terápiában jelenleg négy készítmény érhető el: a három, már jóval régebben a piacon lévő hatóanyag (sildenafil, tadalafil, vardenafil) mellett megjelent a második generációs készítmény; az avanafil. Fontos, hogy a páciens tisztában legyen a kezelés mikéntjével, és az utasításokat pontosan tartsa be. A legújabb szakmai irányvonal szerint mindig a legmagasabb hatóanyagdózissal kezdjük a kezelést, az adagot lefelé titráljuk. A négy különböző hatóanyag lehetővé teszi a páciensek egyéni elvárásainak figyelembevételét, az egyénre szabott terápiát. Fontos a rendszeres ellenőrzés, az orvos-beteg kapcsolat fenntartása.

A foszfodiészteráz-terápiára nem reagáló betegek vizsgálata és kezelése megfelelő centrumokban szakorvosok által történik, hiszen invazív vizsgálatok és kezelési lehetőségek mérlegelése szükséges. Az első vonali kezelésekhez tartozik még a vákuumeszközös terápia; hatékonysága magas, az elégedettség főleg idősebb, ritkábban nemi életet élö, stabil partnerkapcsolattal rendelkező, rosszabb általános állapotú férfiak között jobb. Újabban a hímvessző alacsony intenzitású lökéshullám-kezelésével közöltek talán biztató eredményeket (Li-ESWT).

A merevedési zavarok kezelésében második vonalban választandó a lokális kezelés, a barlangos testbe adott injekcióval. Ez a terápia a súlyosabb ED eseteiben alkalmazott, akarattól függetlenül tud erekciót kiváltani. Az adag beállítása szakorvosi feladat, eközben a páciens elsajátítja a módszert, és később önmagának adja be az injekciót. A hatékonyság nagyon jó, a megelégedettség is hasonló. Létezik ennek a kezelésnek kevésbé invazív, és tegyük hozzá, kevésbé hatékony formája is, a hazánkban nem kapható, de a szomszédos országokból könnyen beszerezhető MUSE (medical urethral system for erection), ami hasonló hatásmechanizmussal, húgycsőbe juttatott hatóanyaggal müködik.

A harmadik vonalba a péniszprotézis-implantáció tartozik. Manapság elsődlegesen az ún. pumpás protéziseket preferáljuk. A barlangos testekbe ültetett cilinderek alapállapotban üresek, a mütét során beültetett pumpa és folyadéktartály segítségével azonban egyszerüen feltölthetők, és így tartós merevedést eredmé- 
nyeznek. Amennyiben a páciens anyagi lehetőségei ezt nem engedik meg, olcsóbb, ún. hajlítható protézist implantálunk. A két szilikoncső a két barlangos testbe kerül beépítésre, és a bennük húzódó ezüstsodrony által a kívánt irányba vagy alakba hajlítható.

\section{A merevedési zavar - erectilis diszfunkció, ED - kezelése}

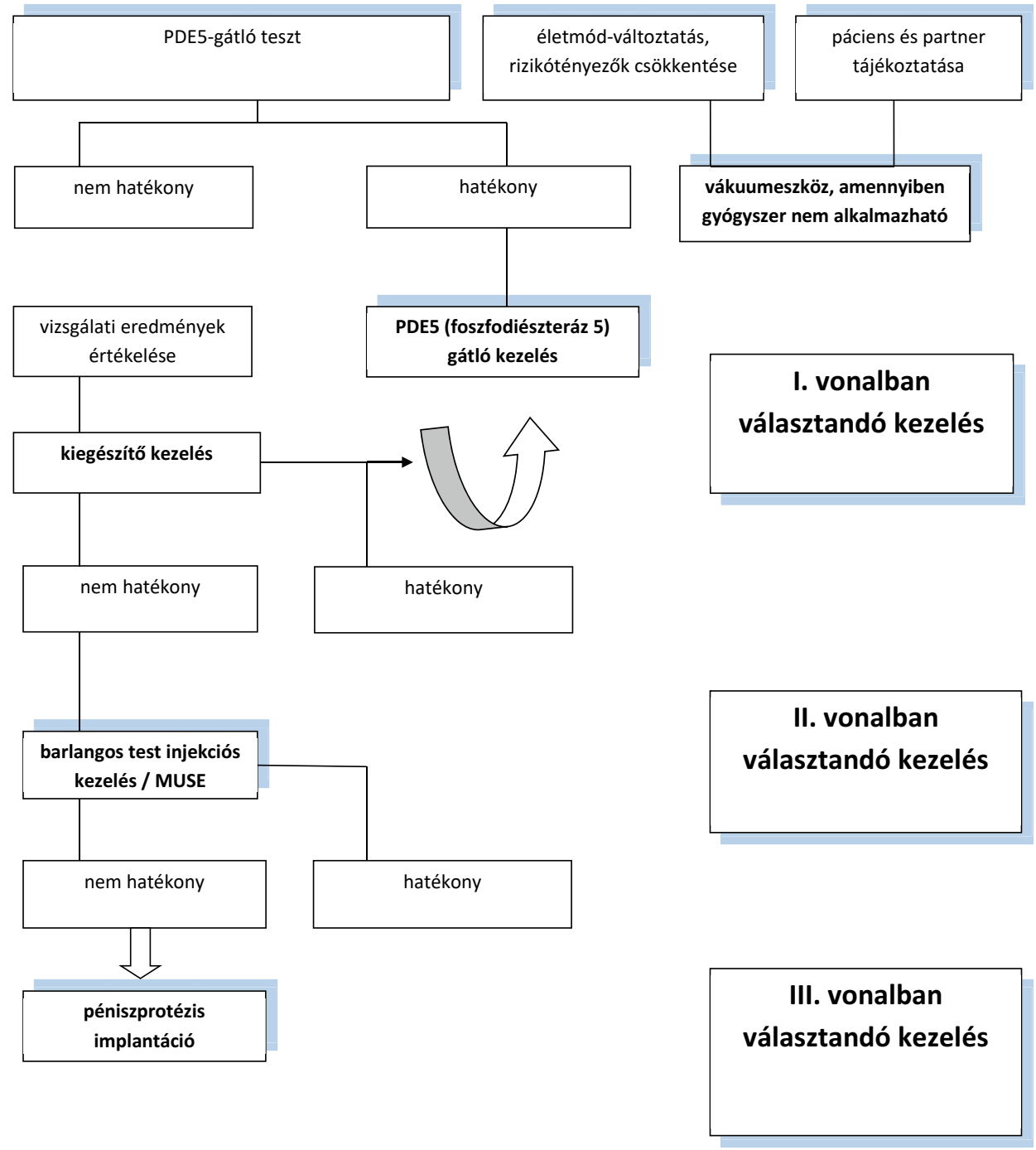

2. ábra. A merevedési zavar kezelésének folyamatábrája 
Fontos megjegyeznünk, hogy ma Magyarországon a merevedési zavar kezelésében elérhető szerek és eszközök semmilyen társadalombiztosítási támogatást nem élveznek.

A szexuálpszichológiai kezelés a tisztán pszichés eredetủ merevedési zavarok esetén vagy bármely páciensnél kiegészító kezelésként alkalmazandó.

Mindazonáltal ne feledjük el, hogy az ED gyógyszeres kezelése tulajdonképpen tüneti terápia, magát a háttérben álló betegséget nem kezeli, célja a kielégítő szexuális kapcsolat és a párkapcsolat helyreállítása, ami igen jelentős faktor az életminőség vonatkozásában. Rendkívül fontos azonban, hogy a szervi rizikótényezőket megvizsgáljuk, az eltéréseket megtaláljuk, és azok megfelelő kezelésével egy későbbi, akár letális következményt tudjunk megelőzni, illetve elhárítani.

\section{KÖVETKEZTETÉS}

Különösen fontos tényező, hogy sok betegnél a szexuális zavar miatt indított kivizsgálás igazol korábban nem ismert betegséget: akár szív- és érrendszeri zavart, magasvérnyomás-betegséget, cukorbetegséget, zsíranyagcsere-eltérést. Ez kiemeli az andrológusok és urológusok felelősségét a diagnosztikában, a szervi kórokok feltérképezésében. Hiába állnak rendelkezésünkre kitủnő hatékonyságú terápiás szerek, az organikus eltérések kivizsgálása elengedhetetlen feladat. Több kiváltó ok még visszafordítható, azaz, ha a beteg időben jelentkezik merevedési zavarával, a gondos kórismézéssel és a terápiás utasítások betartásával súlyos, életet veszélyeztető betegségek kialakulását előzheti meg. A kezelésben rendelkezésünkre álló lehetőségek kiváló hatékonyságúak, de ne feledjük, hogy ezek az ED tüneti terápiáját jelentik. A sok esetben a háttérben meghúzódó súlyos, sokszor később halálos kimenetelü betegség csak a korrekt diagnosztika során fedezhető fel.

\section{AJÁNLOTT IRODALOM}

Broderick, G. A. (2006): Premature Ejaculation: On Defining and Quantifying a Common Male Sexual Dysfunction. The Journal of Sexual Medicine, 3, suppl 4, 295-302. DOI: 10.1111/j.17436109.2006.00304.x

Giuliano, F. - Clement, P. (2006): Serotonin and Premature Ejaculation: From Physiology to Patient Management. European Urology, 50, 454-466. DOI: 10.1016/j.eururo.2006.05.055, https://www.academia.edu/18019549/Serotonin_and_Premature_Ejaculation_From_Physiology_ to_Patient_Management

Hatzimouratidis K. - Giuliano F. - Moncada I. et al. (2019): EAU Guidelines on Male Sexual Dysfunction: Erectile Dysfunction and Premature Ejaculation. European Association of Urology, https://uroweb.org/guideline/male-sexual-dysfunction/

Kopa Zs. (2013): A korai magömlés. Tünet vagy betegség? Magyar Andrológia, XVIII, 1. 3-8. 
Kopa Zs. - Romics I. (2010): A merevedési zavar kezelése. Orvosi Hetilap, 28, 151, 9, 354-357. DOI: $10.1556 / \mathrm{OH} .2010 .28800$

Kopa Zs. - Rusz A. - Riesz P. (2016): Male Sexual Dysfunction. In: Nyirády P. (ed.): Textbook of Urology. Budapest: Semmelweis Publisher, 203-210.

Laumann, E. O. - Nicolosi, A. - Glasser, D. B. et al. (2005): Sexual Problems among Women and Men Aged 40-80 y: Prevalence and Correlates Identified in the Global Study of Sexual Attitudes and Behaviors. International Journal of Impotence Research, 17, 39-57. DOI: 10.1038/ sj.ijir.3901250, https://www.nature.com/articles/3901250

Porst, H. - Montorsi, F. - Rosen, R. C. et al. (2007): The Premature Ejaculation Prevalence and Attitudes (PEPA) Survey: Prevalence, Comorbidities, and Professional Help-Seeking. European Urology, 51, 816-824. DOI: 10.1016/j.eururo.2006.07.004, https://www.academia. edu/14975198/The_Premature_Ejaculation_Prevalence_and_Attitudes_PEPA_Survey_Prevalence_Comorbidities_and_Professional_Help-Seeking

Rosenberg, M. T. - Sadovsky, R. (2007): Identification and Diagnosis of Premature Ejaculation. International Journal of Clinical Practice, 61, 6, 903-908. DOI: 10.1111/j.1742-1241.2007.01337.x 